\title{
Effect of curing conditions on the water vapor sorption behavior of melamine formaldehyde resin and resin- modified wood
}

\author{
Michael Altgen ${ }^{1, *}$ (1), Daniela Altgen ${ }^{1}$, André Klüppel ${ }^{2}$, and Lauri Rautkari ${ }^{1}$ \\ ${ }^{1}$ Department of Bioproducts and Biosystems, Aalto University, P.O. Box 16300, 00076 Aalto, Finland \\ ${ }^{2}$ Wood Biology and Wood Products, Faculty of Forest Science and Forest Ecology, Georg-August University of Göttingen, \\ Büsgenweg 4, 37077 Göttingen, Germany
}

Received: 2 April 2020

Accepted: 8 May 2020

Published online:

18 May 2020

(C) The Author(s) 2020

\begin{abstract}
Impregnation modification of wood with melamine formaldehyde resin reduces the adverse effects caused by moisture uptake, but the underlying modes of action are not fully understood. The present study showed that it is crucial to understand the sorption behavior of the pure resin when interpreting the behavior of resin-modified wood. Furthermore, the applied heat-curing conditions had a significant effect on the moisture uptake of resin-modified wood. At the same resin loads, dry curing conditions were more effective in causing a cell wall bulking effect than wet curing conditions. This reduced the water-accessible cell wall pore volume in dry cured wood and counterbalanced the moisture uptake by the resin. Deuterium exchange measurements suggested that the occupancy of cell wall pores reduced the number of simultaneously active sorption sites. However, there was no evidence that a swelling restraint or reduced mechanical relaxation affected the water sorption of resin-modified wood significantly.
\end{abstract}

\section{Introduction}

Wood has remarkable properties such as a high mechanical strength in relation to its low weight, but its properties are strongly influenced by the uptake (absorption) and release (desorption) of water from the surroundings. The absorption of water by dry wood generally results in a decrease in strength and an increase in dimensions (swelling) until reaching the fiber saturation point, which is reverted when the wood is dried again [1]. Repeated dimensional changes by frequent variations in wood moisture content (MC) will eventually lead to checks and other defects. Therefore, the dimensional instability of wood can affect both aesthetics and functionality of wooden products [2]. Dimensional changes and moisture uptake of wood can be reduced by impregnation modification with thermosetting resins, which forms a composite of wood and resin [3-5]. 
However, there is uncertainty about the underlying modes of action due to a number of effects that act simultaneously on the sorption behavior of resinmodified wood.

Impregnation modification of wood can be performed by using melamine formaldehyde (MF) resins [6-8]. MF resins are formed by reacting primary amino groups in melamine with formaldehyde to form methylol melamines [9]. Methylation of the methylol melamine with methanol improves the miscibility with water and limits self-condensation during storage [10]. This allows the use of aqueous solutions of low molecular weight partially methylated methylol melamine monomers and oligomers for the in situ polymerization inside the wood. The molecules are small enough to not only enter the wood macropores (i.e., cell lumen) but also the nanopores in the water-swollen cell wall [7, 8, 11-13]. Heat curing at elevated temperatures removes the solvent (water) and induces self-condensation of the MF resin via methylene bridges or ether bonds $[9,14]$. This forms highly cross-linked MF resin macromolecules that are no longer water-soluble and are irreversibly fixated in the hierarchical structure of wood, as illustrated in Fig. $1[11,12]$.

When the resin polymerizes within the wood cell wall, it fills the free space between the cell wall matrix polymers to keep the cell wall in a permanently swollen state (Fig. 1). This is commonly denoted as "cell wall bulking" and is typically measured at a macroscopic level by the increase in the dry dimensions of the modified wood blocks. The occupancy of cell wall nanopores by cell wall bulking is known from a large number of modification techniques, where it reduces the accommodation possibility for water [15], and decreases the moisture content (MC) of wood by a constant factor in the hygroscopic [16] and over-hygroscopic range [17]. However, there are further mechanisms that potentially influence the water vapor sorption behavior of MF resin-modified wood. The formation of covalent bonds with accessible hydroxyl $(\mathrm{OH})$ groups in wood would reduce the number of sorption sites for water. Devallencourt et al. [18] found evidence for co-condensation between MF resin and cellulose, but only after curing at elevated temperatures $\left(140{ }^{\circ} \mathrm{C}\right)$ and an alkaline $\mathrm{pH}$. To the best of our knowledge, however, there is no evidence for co-condensation between MF resin and wood. It has also been suggested that the presence of highly cross-linked thermosetting resins

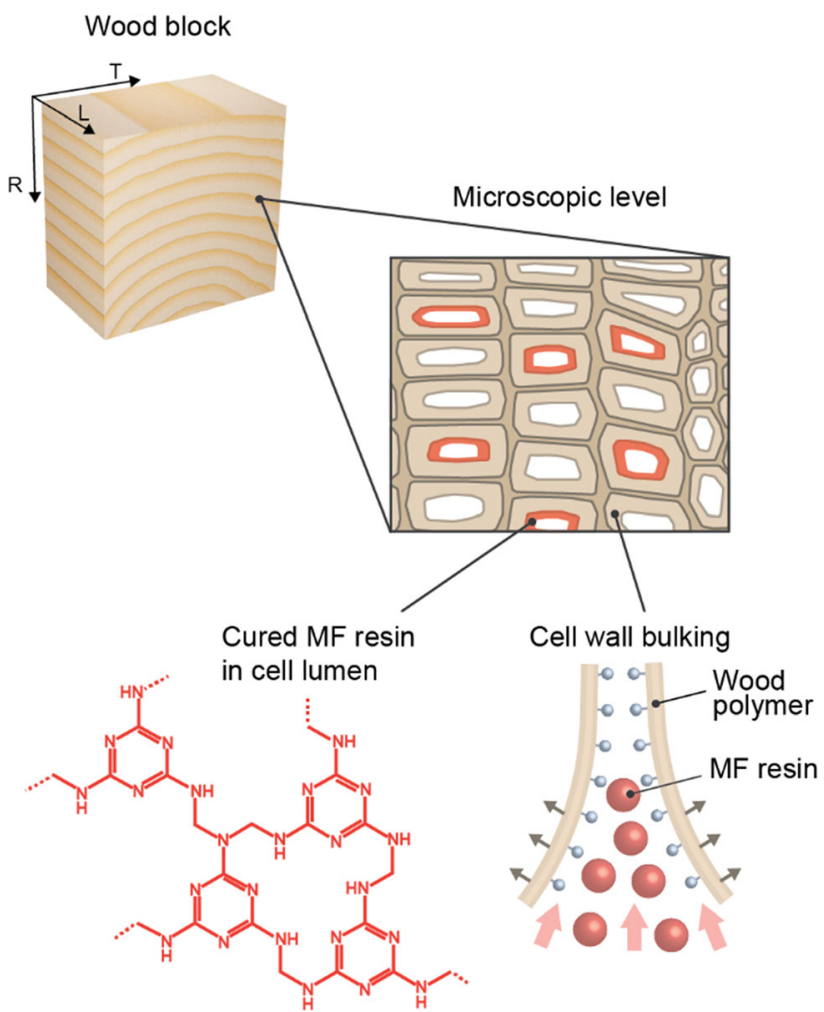

Figure 1 Schematic illustration of the presence of melamine formaldehyde (MF) resin in the hierarchical structure of wood after impregnation modification.

increases the stiffness and restrains the swelling of the cell wall matrix. Thereby, stresses that are created by the uptake of water would no longer be large enough to compete against the swelling restraint, leading to a further reduction in wood $\mathrm{MC}$, particularly at elevated RH [3].

The MC reduction of wood caused by impregnation modification is counterbalanced to some extent by the ability of thermosetting resins to take up moisture $[3,19,20]$. The moisture uptake by thermosetting resins is especially relevant in view of the resin depositions within the cell lumens (Fig. 1) [8], which do not provide a moisture exclusion effect in wood. MF resins contain polar species such as hydroxyls and amines that may interact with water molecules [21]. To our knowledge, however, the water vapor sorption behavior of MF resins has not been studied systematically. There are studies on the liquid water uptake by MF resins, but the reported maximum water uptake varies between less than $10 \%$ and more than $30 \%$ of the initial resin mass [21, 22]. It is likely that the water interaction of MF resins depends on a number of currently unknown factors. 
For example, the moisture absorption of epoxy resins is not only determined by their polar group concentration, but also by their void structure and crosslinking density [20].

Separating the effect of the MC reduction by the impregnation modification on the one hand and the moisture uptake by the resin on the other hand is difficult. In this study, the conditions of the modification process were adapted to cause the independent variation of the resin load and the cell wall bulking in the differently treated wood blocks. This was achieved by impregnating wood blocks with impregnation solutions of different solid contents $(0$, 10 and 25\%), while also applying different heat curing conditions (wet and dry curing). The analysis of treated wood blocks was complemented by the preparation and analysis of pure MF resin that was heat cured without the presence of wood. Analyzing the sorption behavior within the hygroscopic range $(0-95 \% \mathrm{RH})$ and the sorption site accessibility for cured MF resins as well as differently cured wood blocks helped us in identifying the modes of action in the sorption behavior of resin-modified wood.

\section{Materials and methods}

\section{Wood sample preparation and modification}

The wood samples were the same as the ones used in a recent study [23]. In short, Scots pine (Pinus sylvestris L.) sapwood blocks with dimensions of $25 \times 25 \times 10 \mathrm{~mm}^{3}(R \times T \times L)$ were modified with an aqueous solution of partly methylated, low molecular weight MF resin (Madurit MW 840/75WA; INEOS Melamines GmbH, Germany). The wood blocks were vacuum impregnated with the MF resin solution with a solid content of 10 or $25 \%$. A treatment with pure deionized water $(0 \%$ solid content) served as reference. After vacuum impregnation, the wood blocks were left to soak in the solution for $1 \mathrm{~h}$ at ambient pressure, before the MF resin within the wood was heat cured at a temperature sequence of $20,40,60,80,40$ and finally $103^{\circ} \mathrm{C}$, with each temperature being held for ca. $24 \mathrm{~h}$. For wet curing, the wood blocks were wrapped in aluminum foil for the first four temperature steps to prevent drying, while the samples could dry freely during dry curing. After curing, all wood blocks were leached with deionized water for a total of ten days with daily water changes.
The changes in dry mass and dry dimensions (based on cross-sectional area) by the modification were determined after the water leaching and calculated as weight percent gain (WPG, in \%) and cell wall bulking (CWB, in \%) as described previously [24].

\section{Preparation of cured MF resin}

Cured MF resin was prepared by heating ca. $1.5 \mathrm{~g}$ of the MF resin stock solution in an oven. Starting from $40{ }^{\circ} \mathrm{C}$, the temperature was increased stepwise by $30{ }^{\circ} \mathrm{C}$ every $30 \mathrm{~min}$ until reaching the target temperature: 130,160 or $190{ }^{\circ} \mathrm{C}$, which was held for $1 \mathrm{~h}$. One half of the cured MF resin was kept as a solid foam, and the other half was pestled in a mortar to a fine powder.

\section{Raman spectroscopy}

Raman spectra of the MF resin were acquired with a WITec alpha 300 RA Raman microscope (WITec, Ulm, Germany) equipped with a 532-nm frequencydoubled Nd:YAG laser and a DU970-BV EMCCD camera behind a 600 lines $\mathrm{mm}^{-1}$ grating. The measurements were taken with a $20 \times$ air objective (numerical aperture $=0.4$ ), an integration time of $0.5 \mathrm{~s}$ and 10 accumulations. The spectra were baseline corrected using a 5th-order polynomial and normalized to the signal at ca. $974 \mathrm{~cm}^{-1}$.

\section{Scanning electron microscopy}

Wood samples for scanning electron microscopy (SEM) were prepared by heating small pieces (ca. $\left.5 \times 5 \times 10 \mathrm{~mm}^{3} \mathrm{R} \times \mathrm{T} \times L\right)$ in water at ca. $60^{\circ} \mathrm{C}$ for $30 \mathrm{~min}$ before smoothening the transverse or radial surface on a sledge microtome (WSL Lab-Microtome, Swiss Federal Research Institute WSL, Switzerland). Cured MF resin powders were glued on carbon tape without any prior treatment. All SEM samples were dried and coated with gold-palladium before images were taken with a scanning electron microscope (Zeiss, Sigma VP, Germany) using a beam acceleration voltage of $2 \mathrm{kV}$ and a detector for secondary electrons.

\section{Dynamic water vapor sorption}

Prior to the dynamic vapor sorption (DVS) measurements, the wood blocks were milled in a Wiley 
mill to pass through a 30-mesh screen. The MF resin was measured either on solid pieces or on resin powders. The sorption isotherms were determined on a DVS apparatus (DVS intrinsic, Surface Measurement Systems, London, UK) at a temperature of $25{ }^{\circ} \mathrm{C}$. The flow rate was kept constant at $200 \mathrm{sccm}$ using dry nitrogen. A sample mass of ca. $20 \mathrm{mg}$ was placed on the DVS sample pan and subjected to the following relative humidity (RH) sequence: $0,5,15$, $25,35,45,55,65,75,85$ and $95 \% \mathrm{RH}$, which was followed by the same sequence in reverse order until reaching $0 \% \mathrm{RH}$. Each $\mathrm{RH}$ step was maintained until the mass change per minute $(\mathrm{d} m / \mathrm{d} t)$ was less than $0.001 \% \mathrm{~min}^{-1}$ over a $10-\mathrm{min}$ period. The $\mathrm{d} m / \mathrm{d} t$ was calculated using the slope in a 10-min window. The moisture content (MC, in \%) was determined based on the sample mass at the end of each RH step and by relating the mass of water to the dry mass of the sample. The wood moisture content was corrected for the increase in dry mass by the MF resin as described previously [25], and this corrected moisture content was denoted as $M C_{R}$. Furthermore, the $M C_{R}$ ratio was determined by relating the $M C_{R}$ of the treated sample to the $\mathrm{MC}$ of the respective reference sample at the same RH step. Sorption rates $\left(\% \mathrm{mg}^{-1} \mathrm{~min}^{-1}\right)$ were calculated as described by Himmel and Mai [16].

\section{Water vapor sorption over saturated salt solutions}

Short holding times during DVS measurements may mischaracterize the equilibrium moisture content [26], which is why additional sorption tests were conducted over prolonged periods using saturated salt solutions. The remaining wood blocks were split into smaller blocks of ca. $12.5 \times 12.5 \times 10 \mathrm{~mm}^{3}$ $(R \times T \times L)$ using a razor blade. The dry mass was determined after oven-drying at $103{ }^{\circ} \mathrm{C}$ for $24 \mathrm{~h}$ and cooling in a desiccator over silica gel. The uptake of water vapor was measured in absorption from the dry state by conditioning in a desiccator over saturated, aqueous salt solutions. The desiccator was placed in a temperature-controlled room at ca. $20{ }^{\circ} \mathrm{C}$. Saturated, aqueous solutions of $\mathrm{MgCl}_{2}, \mathrm{NH}_{4} \mathrm{Cl}$ and $\mathrm{KNO}_{3}$ were used to obtain RH levels of ca. 33, 79 and $95 \%$, respectively [27]. The mass of each sample was recorded regularly in a random order using a balance with an accuracy of $0.1 \mathrm{mg}$. Starting with $\mathrm{MgCl}_{2}$, the salt solution was exchanged to $\mathrm{NH}_{4} \mathrm{Cl}$ and then to
$\mathrm{KNO}_{3}$ when the change in $\mathrm{MC}$ between two measurements was less than $0.003 \%$ day $^{-1}$ for all sample groups. This calculation was based on the total sample mass per sample group to reduce the impact of a weighing error. The calculation of $\mathrm{MC}$ and $M C_{R}$ was identical to the procedure in "Dynamic water vapor sorption". The $\mathrm{MC}_{\mathrm{R}}$ ratio was determined by relating the $M C_{R}$ of the treated sample to the $M C$ of the reference sample measured at the same time point.

\section{Hydrogen-deuterium exchange}

Hydrogen-deuterium (H-D) exchange measurements were taken on the same samples used for the sorption isotherm measurements. The MF resin that was cured at $130{ }^{\circ} \mathrm{C}$ was not measured, since sorption isotherm and Raman spectroscopic measurements showed that it was not fully cross-linked. The measurements were taken with a sample mass of ca. $20 \mathrm{mg}$ in a DVS apparatus (DVS ET, Surface Measurement Systems, UK). A nitrogen flow of $200 \mathrm{sccm}$ was maintained throughout the measurement using dry nitrogen. Each sample was first dried at $60{ }^{\circ} \mathrm{C}$ for $6 \mathrm{~h}$ using the preheater, followed by a thermal stabilization period at $25{ }^{\circ} \mathrm{C}$ for $2 \mathrm{~h}$. The dried sample was then exposed to $\mathrm{D}_{2} \mathrm{O}(99.9 \%$ atom.; Sigma-Aldrich, Finland) vapor at a target partial pressure of $95 \%$ for $12 \mathrm{~h}$. Finally, the sample was dried as described above. Initial and final dry mass was determined after the 2-h thermal stabilization period. Exchanged $\mathrm{H}\left(\mathrm{H}_{\mathrm{x}}\right.$; in $\left.\mathrm{mmol} \mathrm{g}^{-1}\right)$ and the amount of absorbed $\mathrm{D}_{2} \mathrm{O}$ molecules $\left(\mathrm{MC}_{\mathrm{D} 2 \mathrm{O}}\right.$; in mmol g${ }^{-1}$ ) were calculated according to Eqs. 1 and 2, respectively:

$\mathrm{H}_{\mathrm{x}}\left(\mathrm{mmol} \mathrm{g}^{-1}\right)=1000 \times\left(m_{\mathrm{f}}-m_{\mathrm{i}}\right) /\left(m_{\mathrm{i}} \times \Delta M\right)$

$\mathrm{MC}_{\mathrm{D}_{2} \mathrm{O}}\left(\mathrm{mmol} \mathrm{g}^{-1}\right)=1000 \times\left(m_{\mathrm{c}}-m_{\mathrm{f}}\right) /\left(m_{\mathrm{i}} \times M_{\mathrm{D}_{2} \mathrm{O}}\right)$

where $m_{\mathrm{f}}$ and $m_{\mathrm{i}}$ are the initial and final dry mass (in $\mathrm{mg}$ ), respectively, $m_{\mathrm{c}}$ is the conditioned mass (in $\mathrm{mg}$ ) at the end of the $\mathrm{D}_{2} \mathrm{O}$ vapor exposure, $\Delta M$ is the molar mass difference between deuterium and hydrogen $\left(1.006 \mathrm{~g} \mathrm{~mol}^{-1}\right)$, and $M_{\mathrm{D}_{2} \mathrm{O}}$ is the molar mass of $\mathrm{D}_{2} \mathrm{O}\left(20.0276 \mathrm{~g} \mathrm{~mol}^{-1}\right)$. Additionally, $\mathrm{H}_{\mathrm{x}}$ and $\mathrm{MC}_{\mathrm{D} 2 \mathrm{O}}$ were corrected for the additional dry mass of the modified wood by the MF resin, as described previously [25]. Thereby, the mass of exchanged $\mathrm{H}$ or 
absorbed $\mathrm{D}_{2} \mathrm{O}$ was related to the dry wood mass instead of the dry sample mass.

\section{Infrared spectroscopy}

The effect of H-D exchange on the Fourier transform infrared (FTIR) spectra was measured on MF resin that was cured at $190^{\circ} \mathrm{C}$. The measurements were taken on the resin powder, either after the H-D measurements described in 2.7 or after applying the same DVS sequence using $\mathrm{H}_{2} \mathrm{O}$ instead of $\mathrm{D}_{2} \mathrm{O}$. The spectra were collected on a FTIR spectrometer (Spectrum Two, PerkinElmer, USA) equipped with an ATR unit and a diamond crystal within the wave number region $4000-700 \mathrm{~cm}^{-1}$ using a resolution of $4 \mathrm{~cm}^{-1}$ and 8 accumulations.

\section{Results and discussion}

\section{Spectroscopic analysis of cured MF resin}

The MF resin formed a hard and brittle foam after curing (Fig. 2a). Grinding the cured resin produced a fine powder, and SEM observation showed that most of these particles were in the range of a few hundred micrometers in size (Fig. 2b). The particles were solids with a relatively smooth surface and only very few pores with less than one micrometer in diameter. Changes in the MF resin caused by heat curing at different temperatures were analyzed by Raman spectroscopy (Fig. 2c). The most intense band was found at ca. $974 \mathrm{~cm}^{-1}$, which was assigned to the triazine-ring nitrogen radial in-phase vibration of the melamine [28]. This band was also used for normalization of the MF resin spectra, since it is known to be insensitive to the resin cure $[29,30]$. Changes in the Raman spectra by the heat cure of MF resin at different temperatures were in line with the sequence of curing reactions that was suggested previously [14]. The polycondensation of the MF resin reduced the signal of the band at ca. $677 \mathrm{~cm}^{-1}$ and increased the signal of the band at ca. $745 \mathrm{~cm}^{-1}$, which were assigned to in-plane and out-of-plane bending vibrations of the triazine ring of melamine, respectively $[28,30]$. With increasing temperature, curing also resulted in the continuous decrease at ca. $897 \mathrm{~cm}^{-1}$, which was assigned to ether bonds, and at 2800-3050 $\mathrm{cm}^{-1}$, which was assigned to C-H stretching [29]. These spectral changes were in line with the cleavage of the methyl ether groups in the partially methylated MF resin [23] and the transformation of intermediate ether linkages to methylene bridges by elimination of formaldehyde at elevated temperatures [14]. The methylene bridge formation during curing was observed by the loss in the signal of methylol groups at ca. $1448 \mathrm{~cm}^{-1}$ along with a broadening of the band to lower wave numbers with a shoulder at ca. $1426 \mathrm{~cm}^{-1}$ [23]. The decrease in methylol group content was further shown by the disappearance of the shoulder at around $1000 \mathrm{~cm}^{-1}$ in uncured MF resin $[29,31]$.
Figure 2 Raman spectra and morphological structure of cured MF resin. a Image of a solid MF resin foam after curing at $160{ }^{\circ} \mathrm{C}$ with scale in $\mathrm{mm} ; \mathbf{b}$ SEM images of $\mathbf{a}$ particle after grinding the cured MF resin; and c Raman spectra of uncured and differently cured MF resins in the wave number range between 250 and $3600 \mathrm{rel} \mathrm{cm}^{-1}$.
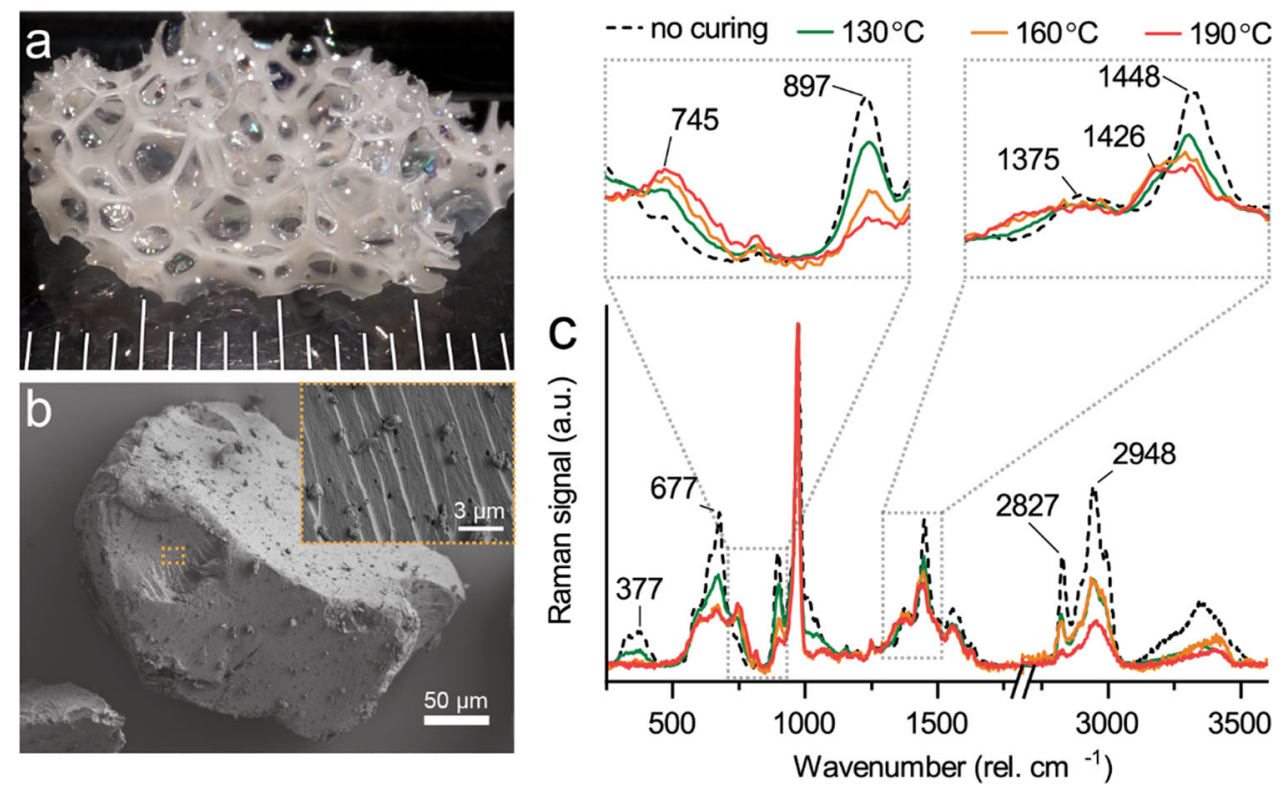


\section{Sorption behavior of cured MF resin}

Cured MF resins contain polar groups that may interact with water molecules [21], but the magnitude and the dependence of the water sorption on the curing conditions have not been studied. The sorption behavior of the cured MF resin was measured on small, solid pieces and on powders after grinding the cured resin. The absorption (Fig. 3a) and desorption isotherms (Fig. 3b) showed clear differences between MF resin cured at mild temperatures $\left(\leq 130{ }^{\circ} \mathrm{C}\right)$ and resins that were cured either at intermediate $\left(\leq 160{ }^{\circ} \mathrm{C}\right)$ or a high $\left(\leq 190^{\circ} \mathrm{C}\right)$ temperatures. In absorption, the MC of the differently cured resins was in a similar range up to a $\mathrm{RH}$ of ca. $55 \%$, but there was a steep increase in MC for the mildly cured MF resin. The latter reached a MC of nearly 25\% at 95\% $\mathrm{RH}$, while the $\mathrm{MC}$ of the other resins did not exceed $10 \%$. In desorption, the MC of mildly cured MF resin decreased with a clear hysteresis effect, which was almost absent in intermediately or highly cured MF resin (Fig. 3c). Presumably, MF resin that was cured at mild temperatures had a lower crosslinking density and, consequently, a lower restraint to water-induced, structural rearrangements. Thereby, absorption of water could increase the free space in the resin to accommodate water and to enhance the accessibility of polar groups to water, as has been shown for epoxy resins [20]. In contrast, the curing at intermediate and high temperatures formed resins with a high cross-linking density that provided a restraint to structural rearrangements and prevented the steep increase in MC at elevated $\mathrm{RH}$.

Although the Raman spectra showed differences in the MF resin after curing at $160{ }^{\circ} \mathrm{C}$ and $190{ }^{\circ} \mathrm{C}$, the sorption isotherms were similar and resin cured at $160{ }^{\circ} \mathrm{C}$ even had slightly lower MC values (Fig. 3a, b). However, the differences in the Raman spectra did not provide clear evidence for a difference in crosslinking density and may have also been caused by the transformation of intermediate ether linkages to methylene bridges [14]. Furthermore, the particle size had a larger influence on the $\mathrm{MC}$ of the resins cured at 160 and $190{ }^{\circ} \mathrm{C}$ than the curing temperature. Measuring the resins in form of powder increased the MC of both resins compared to the measurement of macroscopic particles, presumably due to a higher surface area in powders compared to solid MF resin. In contrast, a clear size effect was not observed for MF resin that was cured at $130{ }^{\circ} \mathrm{C}$. Presumably, water-induced structural rearrangements of the insufficiently cross-linked MF resin opened up the
Figure 3 Sorption behavior of cured MF resin: absorption isotherms (a), desorption isotherms (b) and hysteresis (c) measured in the hygroscopic range (0-95\% $\mathrm{RH})$, exchanged hydrogen and absorbed $\mathrm{D}_{2} \mathrm{O}$ measured by $\mathrm{H}-\mathrm{D}$ exchange (d), as well as FTIR spectra of cured MF resin $\left(190{ }^{\circ} \mathrm{C}\right)$ after drying and $\mathrm{H}-\mathrm{D}$ exchange (e). Each column in $(\mathbf{d})$ represents the average of three replicates, and the error bars show minimum and maximum.
Solid: $\rightarrow-130^{\circ} \mathrm{C} \longrightarrow 160^{\circ} \mathrm{C} \longrightarrow 190^{\circ} \mathrm{C}$

Powder: $\cdots \cdots 130^{\circ} \mathrm{C} \cdots 160^{\circ} \mathrm{C} \cdots \triangle \cdots 190^{\circ} \mathrm{C}$
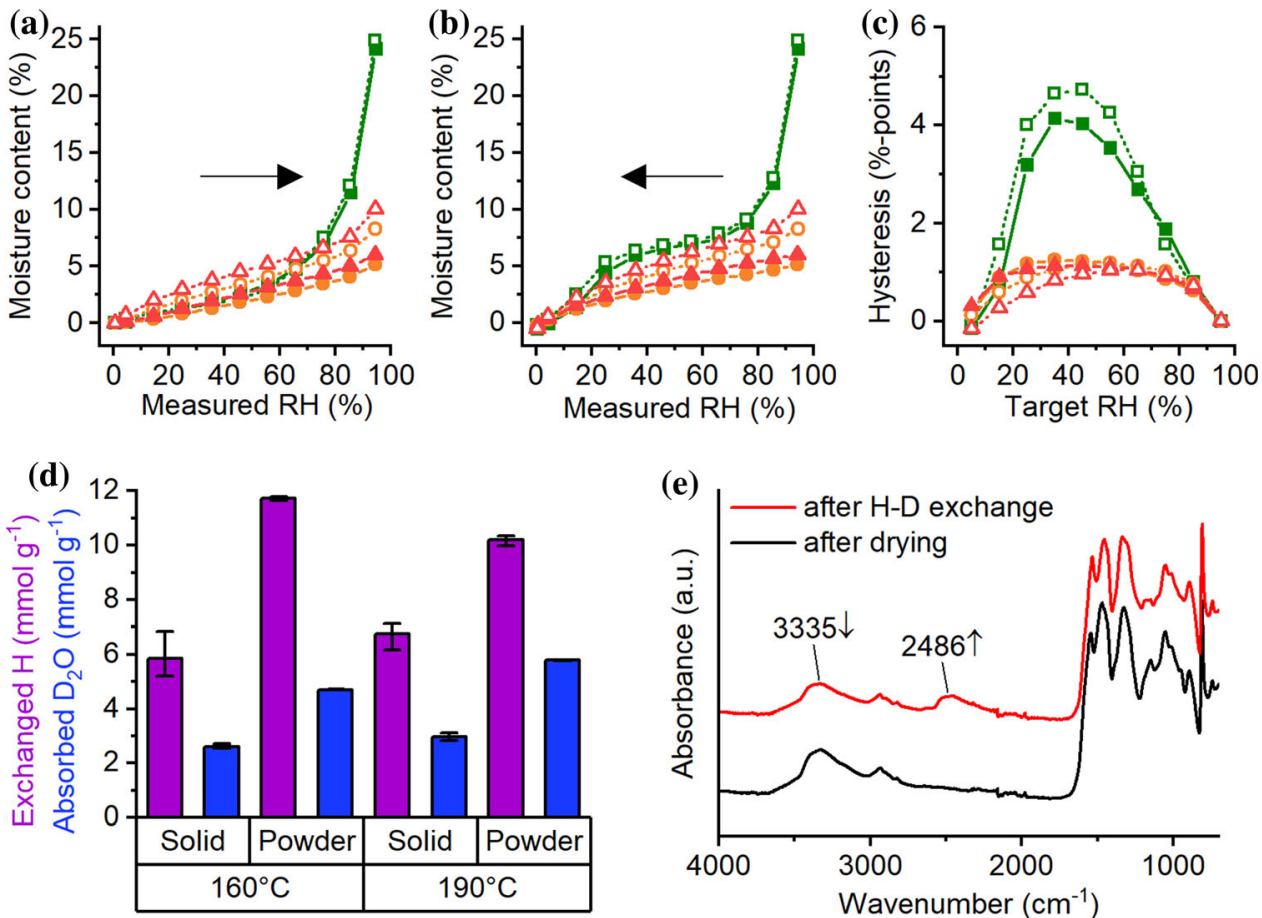

(e)

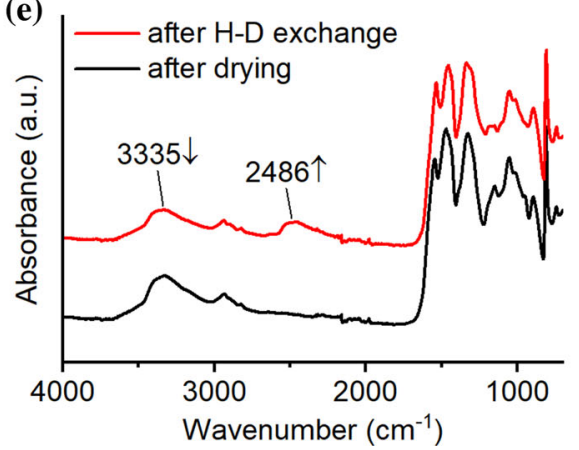


structure and revealed more polar groups for water interactions even without an increase in the surface area of the resin, as suggested for flexible epoxy resins [20].

The effect of different particle sizes on the resins that were cured at 160 and $190{ }^{\circ} \mathrm{C}$ was further evaluated by $\mathrm{H}-\mathrm{D}$ exchange measurements (Fig. $3 \mathrm{~d}$ and e). During $\mathrm{H}-\mathrm{D}$ exchange, $\mathrm{D}_{2} \mathrm{O}$ molecules absorb to water-accessible sorption sites, which then have their hydrogen $\left(\mathrm{H}\right.$, or $\left.{ }^{1} \mathrm{H}\right)$ exchanged to deuterium $(\mathrm{D}$, or $\left.{ }^{2} \mathrm{H}\right)$. This can be determined gravimetrically based on the dry mass increase by ca. $1 \mathrm{~g}$ per mol exchanged $\mathrm{H}$ or spectroscopically [25]. FTIR spectroscopy confirmed the deuteration of the MF resin by the shift of the band at ca. $3335 \mathrm{~cm}^{-1}$, which was assigned to O$\mathrm{H}$ and $\mathrm{N}-\mathrm{H}$ stretching vibrations [32] (Fig. 3e). After the $\mathrm{H}-\mathrm{D}$ exchange, the absorbance at ca. $3335 \mathrm{~cm}^{-1}$ decreased and a new band was formed at ca. $2486 \mathrm{~cm}^{-1}$, due to effect of the higher mass of deuterium on the molecular bond vibrations. Gravimetric $\mathrm{H}-\mathrm{D}$ exchange measurements on MF resins in solid form gave 5.9 and $6.8 \mathrm{mmol} \mathrm{g}^{-1}$ exchanged $\mathrm{H}$ as well as 2.6 and $3 \mathrm{mmol} \mathrm{g}^{-1}$ absorbed $\mathrm{D}_{2} \mathrm{O}$ for the resins cured at 160 and $190{ }^{\circ} \mathrm{C}$, respectively (Fig. 3d). When assuming the exchanged $\mathrm{H}$ to accurately represent the number of sorption sites for water, these values either suggested that each (deuterated) water molecule absorbed to approximately two sorption sites, or that not all sorption sites were simultaneously active in water sorption during the conditioning at $95 \% \mathrm{RH}$. Measuring the MF resin in powder form almost doubled these values, while keeping the ratio of absorbed $\mathrm{D}_{2} \mathrm{O}$ per exchanged $\mathrm{H}$ nearly unchanged. This illustrated a strong dependence of the MC on the sorption site accessibility in fully cured MF resin. Since the high cross-linking density hindered the ability of water to open up the resin structure to reveal excluded polar groups, the accessible sorption site concentration was dependent on the resin's surface area.

\section{Macroscopic and microscopic changes in wood by resin modification}

Changes in dry mass and dimensions of the wood blocks by the different solid contents and curing conditions are shown as weight percent gain (WPG) and cell wall bulking (CWB) in Table 1. The observed changes corresponded to earlier results [24, 33], and changes in mass and dimensions of the treated wood blocks have already been discussed in detail in a previous study [23]. The leaching of extractives resulted in a negative weight percent gain for the reference wood blocks ( $0 \%$ solid content), but the weight percent gain of modified wood increased with increasing solid content, irrespective of the curing conditions. While this showed the successful fixation of the MF resin within the hierarchical structure of wood, a positive cell wall bulking that indicates the fixation of the resin within the wood cell wall was only measured after dry curing.

Dry curing conditions may have promoted a faster cell wall diffusion of the resin, because removing the solvent (water) from the lumen at low temperatures increased the concentration gradient between lumen and cell wall [24]. Recently, however, similar amounts of MF resin were found in wet and in dry cured latewood cell walls [23]. It was speculated that an additional cell wall diffusion of MF resin under dry curing conditions was limited to short distances near the lumen interface. Furthermore, it was shown that the inability of wet curing conditions to cause a positive cell wall bulking effect was primarily caused by the alkaline hydrolysis of cell wall constituents, which counterbalanced the cell wall bulking effect by the MF resin. However, irrespective of the exact reasons for the absence of the cell wall bulking effect, wet curing did not reduce the water-available pore space in the cell walls. Such a reduction was only achieved when the dry dimensions of the wood blocks were increased under dry curing conditions, which reduced the volumetric margin between the dry and the water-saturated state [23].

SEM observations of the resin-modified wood blocks showed a large number of cell lumens that were filled with cured MF resin (Fig. 4). Resin

Table 1 Weight percent gain (WPG, \%) and cell wall bulking (CWB, \%) measured after water leaching. The table shows average values based on five replicates based on the data from [20]. Standard deviations are shown in parentheses

\begin{tabular}{llll}
\hline Solid content $(\%)$ & Curing & WPG $(\%)$ & CWB $(\%)$ \\
\hline 0 & Dry & $-1.6(0.18)$ & $-1.5(0.25)$ \\
& Wet & $-1.8(0.11)$ & $-2.1(0.31)$ \\
10 & Dry & $11.9(1.98)$ & $0.7(0.63)$ \\
& Wet & $10.31(1.29)$ & $-0.4(0.89)$ \\
25 & Dry & $26.05(4.68)$ & $3.6(1.03)$ \\
& Wet & $28.24(2.97)$ & $-1.1(0.73)$ \\
\hline
\end{tabular}


deposits in the cell lumen were found after dry and wet curing, but the shape of these deposits differed depending on the curing conditions, as shown recently [23]. In dry cured cells, the resin formed circular layers at the interface between cell wall and lumen (Fig. 4a), while solid resin droplets were formed under wet curing conditions (Fig. 4b). The different shapes of the lumen deposits are further illustrated in Supplementary Fig. S.1 and Fig. S.2 based on SEM images taken on radial surfaces. MF resin deposits in the cell lumen have been observed in a number of studies that applied various treatment conditions, and both, resin droplets and circular resin layers, have been reported $[6-8,34]$. The present results indicated that the presence of water in the wood during the curing step had a significant effect on the shape of the lumen deposits. Presumably, dry curing removed water at mild temperatures before polycondensation of MF resin occurred; hence, the resin first precipitated on the lumen surface before hardening as circular layer. In contrast, during wet curing the impregnated wood blocks were heated to $80{ }^{\circ} \mathrm{C}$, while water remained within the wood. This may have promoted the formation of MF microspheres that were too large to be removed from the cells when drying was induced by unwrapping the wood blocks at a later curing stage.

\section{Water vapor sorption of resin-modified wood}

The presence of MF resin inside the hierarchical wood structure not only changes the total amount of water and sorption sites involved in wood/water interactions, but also increases the dry sample mass. The MC and the concentration of exchanged $\mathrm{H}$ of
Figure 4 SEM images of transverse sections of latewood cells in dry cured (a) and wet cured (b) wood blocks that were treated using an impregnation solution with $25 \%$ solid content.
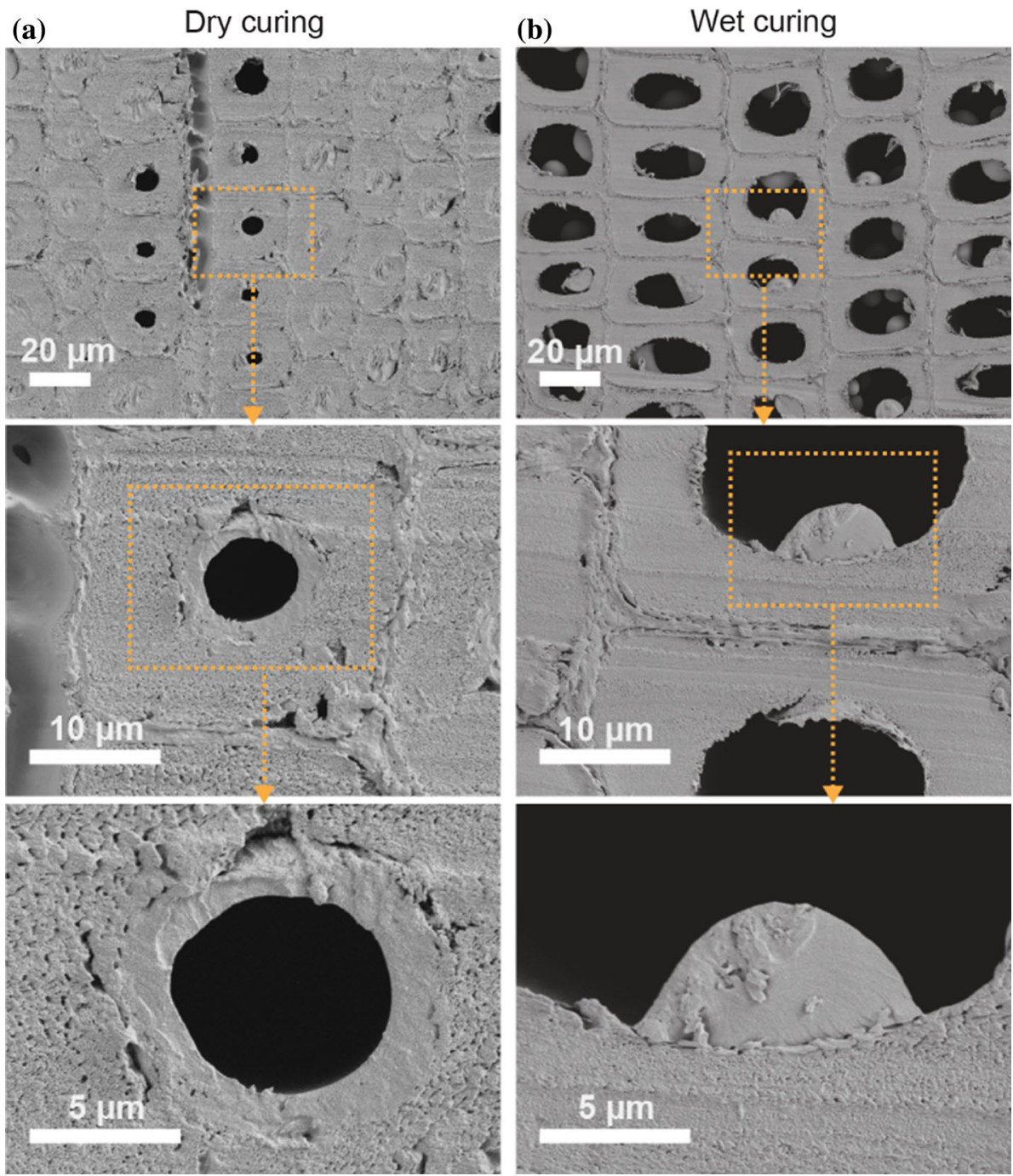
modified wood are reduced by this mass increase, if the dry sample mass is used as the reference mass for their calculation [25, 35]. Although the calculations are technically correct, it is difficult to differentiate between the effect of an increase in reference mass and an actual reduction in the amount of absorbed water, particularly when comparing samples with different WPG levels. This effect can be circumvented by using the oven-dry wood weight prior to the modification process as a reference mass $[25,35]$. This overestimates the MC of the resin-modified wood, because the water absorbed by the resin also contributes to the water mass. However, it eases the interpretation of the results when changes in MC are only caused by changes in water mass (numerator) and not by changes in reference mass (denominator).

The water sorption behavior of the wood particles was analyzed in the hygroscopic range $(0-95 \% \mathrm{RH})$ by DVS measurements (Fig. 5). Similar effects were recorded in absorption and desorption. Below ca. $80 \% \mathrm{RH}$, all modified samples showed a higher $\mathrm{MC}_{\mathrm{R}}$ compared to the reference samples (Fig. 5a and d) and the increase in $M C_{R}$ was higher for samples with higher WPG (impregnated with 25\% solid content). This can be assigned to the additional water absorption by the MF resin. Above ca. $80 \% \mathrm{RH}$, the differences in $M C_{R}$ between modified and reference samples became smaller and the $M C_{R}$ of dry cured samples even decreased below the reference $M C_{R}$. After conditioning at $95 \% \mathrm{RH}$, the $\mathrm{MC}_{\mathrm{R}}$ of dry cured samples decreased with increasing solid content of the impregnation solution, while wet cured samples showed the opposite trend.

It may be assumed that the higher $\mathrm{MC}_{\mathrm{R}}$ of wet cured wood was caused by insufficient cross-linking of the MF resin, particularly because the curing temperature applied to the wood blocks was lower than the temperature applied to cure the pure MF resin. However, the prolonged heat curing and the catalytic effect of the acidic wood on methylene bridge formation resulted in the complete cure of the MF resin within the wood [23]. This was particularly evident after wet curing, and the Raman spectrum of lumen deposits in wet cured wood was very similar to the spectra of the resin after curing at $160-190{ }^{\circ} \mathrm{C}$ (Supplementary Fig. S.3). Therefore, differences in the MF resin cure are unlikely to be the reason for the observed differences in water vapor sorption of dry and wet cured wood blocks.
The effect of the modifications was better visible when looking at the course of the $M C_{R}$ ratios in the hygroscopic range (Fig. $5 \mathrm{~b}$ and e). The $\mathrm{MC}_{\mathrm{R}}$ ratio relates the $M C_{R}$ of the modified samples to the $M C_{R}$ of the reference sample at each $\mathrm{RH}$ step. The resinmodified wood showed a decrease in the $M C_{R}$ ratio with increasing $\mathrm{RH}$. The slope in the course of the $M C_{R}$ ratio in dependence on the $R H$ was mostly independent of the curing conditions, but a slightly larger slope was found for wood with higher resin loads (25\% solid content). A decrease in the $M C_{R}$ ratio with increasing $\mathrm{RH}$ for wood treated with thermosetting resins was also observed by Hosseinpourpia et al. [3]. They compared this to the effect of cross-linking treatments of wood that form covalent bonds between cell wall matrix polymers to restrict the swelling of the wood cell wall matrix by water sorption $[15,16,36]$. However, the decrease in $M C_{R}$ ratio caused by resin treatments may not rely on any interaction of wood and resin or a swelling restraint of the cell wall matrix. Instead, it can be explained by the sorption behavior of fully cured MF resin. The $\mathrm{MC}$ of the resin was in nearly linear proportion to the $\mathrm{RH}$, while the sorption isotherm of (untreated) wood has a sigmoid shape. Therefore, sorption of the resin contributed significantly to the $M C_{R}$ of modified wood at low $\mathrm{RH}$, but its proportion decreased as the isotherm of wood underwent a steep increase in MC at elevated $R H$. Therefore, the decreasing $M C_{R}$ ratio did not imply a reduction of cell wall matrix swelling. This is supported by a previous study based on the same samples, which showed that the volumetric margin between dry wood and water-saturated wood was only reduced by an increase in dry wood dimensions due to cell wall bulking and not by a reduction in water saturated dimensions [23].

Compared to wet cured wood treated at the same solid content, a lower $M C_{R}$ ratio was determined for dry cured wood (Fig. $5 b$ and e). Especially for wood treated with a $25 \%$ solid content, the $\mathrm{MC}_{\mathrm{R}}$ ratio of dry cured wood was reduced by a constant factor over the entire hygroscopic range compared to wet cured wood. This difference correlated with a higher cell wall bulking after dry curing compared to wet curing. It is in line with the proposed effect of cell wall bulking due to wood acetylation, which has been shown to cause a nearly constant reduction in $M C_{R}$ in the hygroscopic [16] and over-hygroscopic range [17]. In dry cured wood, the reduction in $M C_{R}$ by cell wall bulking was large enough to compensate for the 
Dry curing: $-x-$ Ref $\cdots-\Delta-10 \%-\Delta-25 \%$

Wet curing: $-x-$ Ref $\cdots \circ \cdots 10 \% \longrightarrow-25 \%$
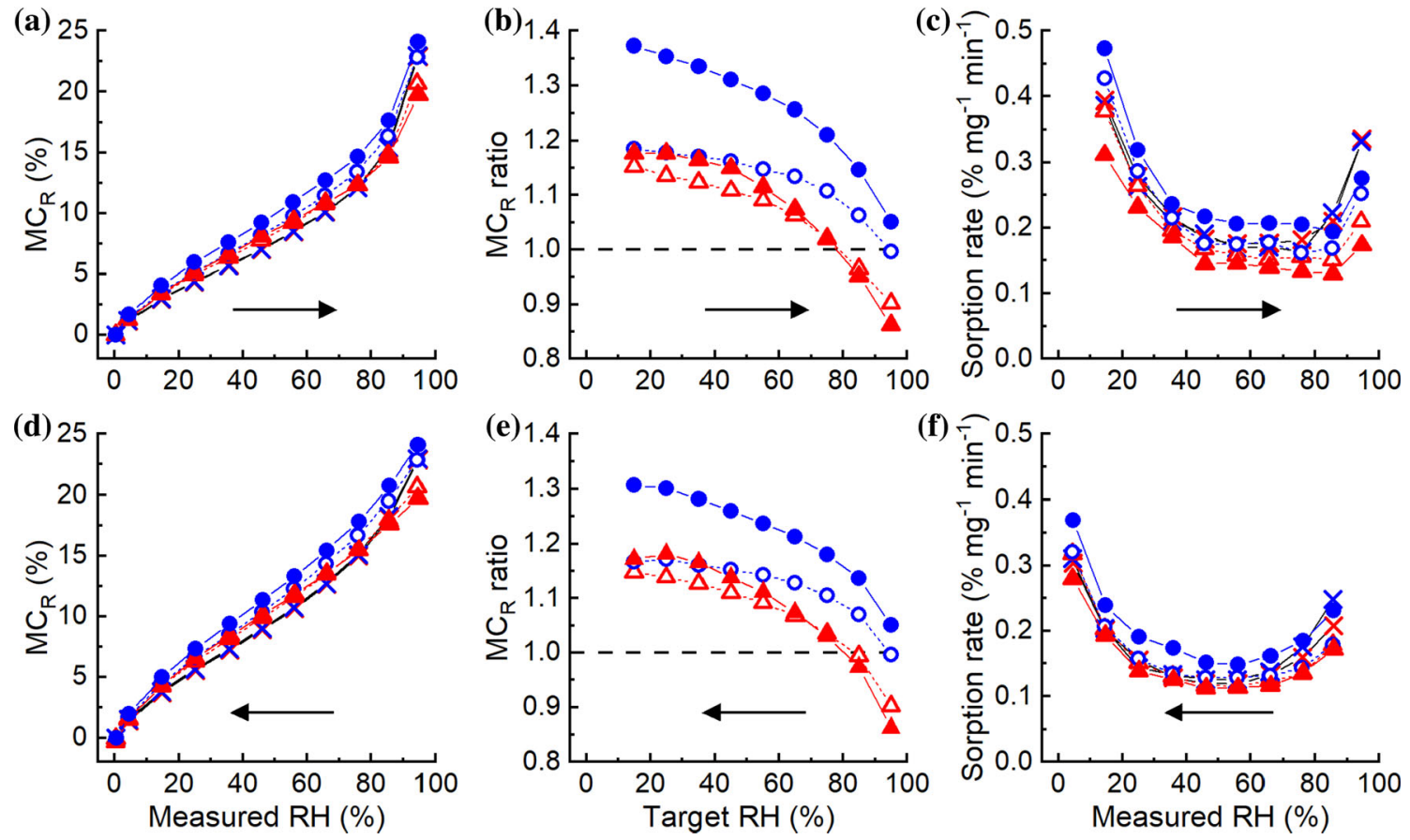

Figure 5 Results of the dynamic water vapor sorption measurements on wood particles: sorption isotherms (a and $\mathbf{d}$ ), $M C_{R}$ ratios ( $b$ and $\mathbf{e}$ ) and sorption rates ( $\mathbf{c}$ and $\mathbf{f}$ ) measured in

additional water absorption of the $\mathrm{MF}$ resin, as shown by an $M_{R}$ ratio below 1 at $95 \% R H$. This also provides an explanation for the nearly identical $M C_{R}$ ratio at $95 \% \mathrm{RH}$ for dry cured wood treated with different solid contents. A higher solid content increased the amount of resin in wood that absorbed water, while it also reduced the amount of water that could be accommodated in the wood cell wall due to a higher cell wall bulking.

However, it should be noted that the MC measured at the end of each RH step in the DVS may underestimate the actual equilibrium MC of wood, due to short holding times [26]. This may especially apply to modified wood, since the modification could hinder the fast relaxation so that it takes longer to reach an equilibrium state [37]. Furthermore, the circular resin layer at the interface between cell wall and lumen in dry cured wood may delay the diffusion of water into the cell wall. This is in line with the lower sorption rate in the resin-modified wood, particularly after dry curing, compared to the reference samples (Fig. 5c and $\mathrm{f})$. Therefore, the DVS measurements were validated by measuring $M_{R}$ changes during absorption from $0 \% \mathrm{RH}(\mathrm{a}-\mathrm{c})$ and in desorption from $95 \% \mathrm{RH}(\mathbf{d}-$ f). The dashed line (b) and (e) highlights the reference value.

conditioning of wood blocks over different salt solutions in the course of several weeks and months.

It took much longer to reach a stable $\mathrm{MC}_{\mathrm{R}}$ during conditioning over salt solutions compared to the DVS measurements (Fig. 6a), and there were deviations in $\mathrm{MC}_{\mathrm{R}}$ between the two methods (Supplementary Table S.1). Not only did the sample dimensions differ significantly, but the results may have also been influenced by the stagnant atmosphere within the desiccator in contrast to the continuous flow of water vapor within the DVS apparatus [38]. Furthermore, the actual RH was not measured over the salt solutions and it is reasonable to assume that fluctuations in room temperature resulted in a reduction in $\mathrm{RH}$ particularly at $95 \%$ target $\mathrm{RH}$, as explained in detail by Strømdahl [39]. However, the comparison of the absolute $M C_{R}$ values was not the purpose of the additional long-term conditioning over salt solutions. For the present study, the change in $M C_{R}$ in relation to the $\mathrm{MC}$ of reference samples was more relevant and this was illustrated by the course of the $M C_{R}$ ratio over time in Fig. $6 \mathrm{~b}$. The magnitude of the $M C_{R}$ ratios at the different conditioning steps was in agreement with the DVS results. Furthermore, the 

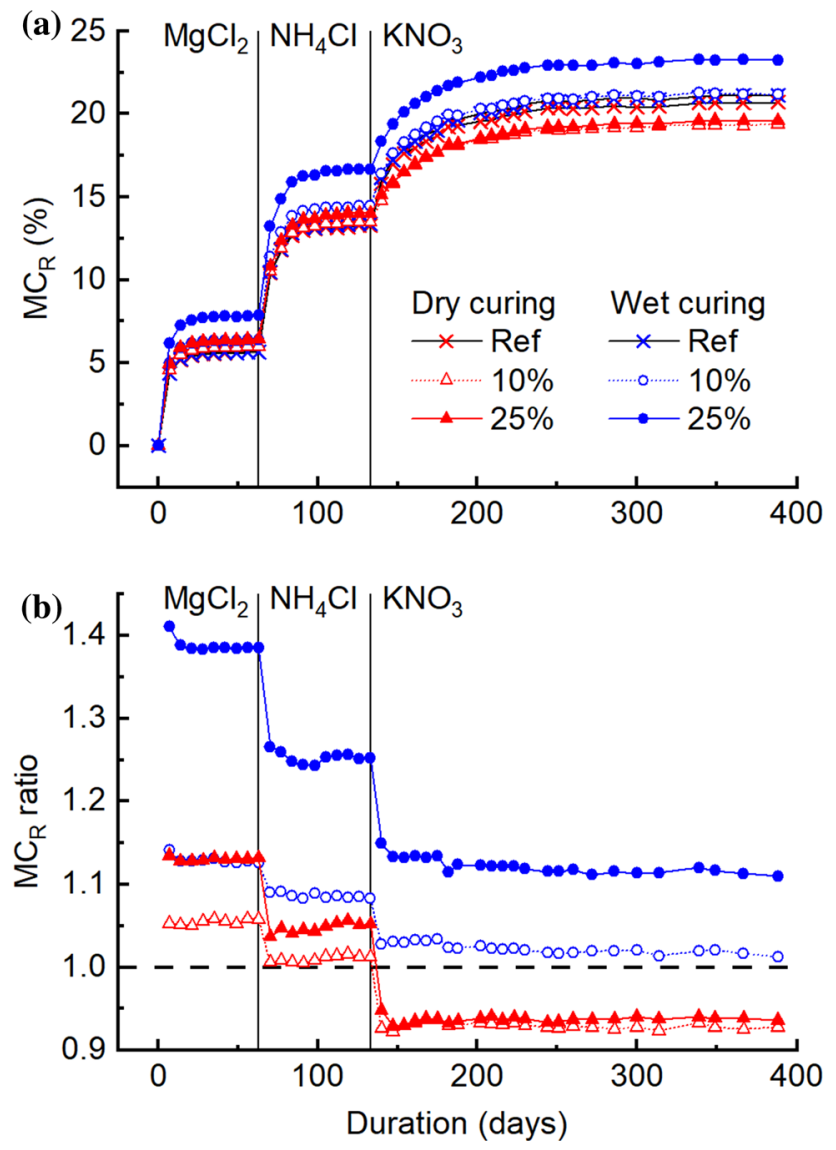

Figure 6 Conditioning of wood blocks over saturated, aqueous salt solutions: $\mathrm{MC}_{\mathrm{R}}\left(\right.$ in $\%$; a) and $\mathrm{MC}_{\mathrm{R}}$ ratio (b) in dependence on the conditioning duration over $\mathrm{MgCl}_{2}, \mathrm{NH}_{4} \mathrm{Cl}$ and $\mathrm{KNO}_{3}$ solutions. The dashed line in (b) highlights reference $M_{R}$ (average of reference samples). Each data point shows an average of four samples.

nearly constant $M C_{R}$ ratios over time at each RH step suggested that the results were not biased by hindered relaxation in the modified wood that would have delayed the attainment of an equilibrium state in comparison with the reference samples.

\section{Accessible sorption sites in resin-modified wood}

Accessible sorption sites in resin-modified wood were quantified by $\mathrm{H}-\mathrm{D}$ exchange, which has already been applied to untreated wood $[40,41]$ as well as to wood modified with carboxylic acid anhydrides [42] or by heat [43]. The results are displayed for two different calculations, using either the dry sample mass or the dry wood mass as reference mass (Fig. 7). The amount of $\mathrm{D}_{2} \mathrm{O}$ that was absorbed at a target $\mathrm{RH}$ of $95 \%$ showed the same trends as the $M C_{R}$ measured in $\mathrm{H}_{2} \mathrm{O}$ vapor at the same target $\mathrm{RH}$ (Fig. 7a). In particular, dry curing reduced the amount of absorbed $\mathrm{D}_{2} \mathrm{O}$ with increasing solid content of the impregnation solution, while the opposite trend was observed after wet curing. The latter was an effect of the $\mathrm{D}_{2} \mathrm{O}$ absorption by the resin; hence, the amount of absorbed $\mathrm{D}_{2} \mathrm{O}$ in wet cured wood decreased below the amount in the reference samples $(0 \%$ solid content) when the dry sample mass was used as a reference mass.

The curing conditions also affected the amount of exchanged $\mathrm{H}$, which is an indication of the number of sorption sites (Fig. $7 \mathrm{~b}$ ). The concentration of exchanged $\mathrm{H}$ increased with the solid content of the impregnation solution, but it increased less for dry cured than for wet cured wood. This increase was also measured when the dry sample mass was used as a reference mass for the calculation, which showed that the amount of exchanged $\mathrm{H}$ in the in situ cured MF resin exceeded the concentration that was
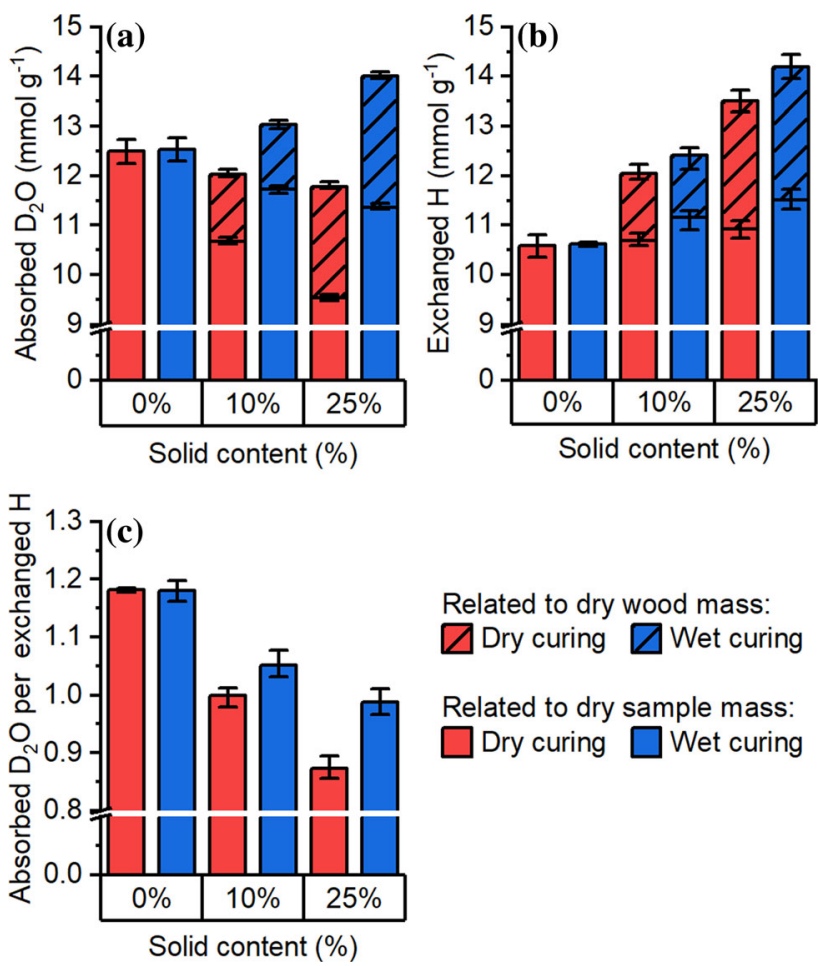

Related to dry wood mass: $\triangle$ Dry curing $\square$ Wet curing

Related to dry sample mass: $\square$ Dry curing $\square$ Wet curing

Figure 7 Results of the H-D exchange measurements on wood particles: absorbed $\mathrm{D}_{2} \mathrm{O}$ molecules (in mmol $\mathrm{g}^{-1}, \mathbf{a}$ ), exchanged hydrogen (in mmol g ${ }^{-1}, \mathbf{b}$ ) and absorbed $\mathrm{D}_{2} \mathrm{O}$ molecules per exchanged hydrogen (c) in dependence on the solid content of the impregnation solution. Each column represents the average of three replicates, and the error bars show minimum and maximum. Note the breaks in the $y$-axes. 
measured for the reference wood samples (ca. $10.6 \mathrm{mmol} \mathrm{g}^{-1}$ ). This was in line with the size effect on accessible sorption sites measured for the cured MF resin. The in situ polymerization of the resin within the wood cells ensured the spatial separation of small resin agglomerates, as shown by SEM, which resulted in a high resin surface area and a high sorption site accessibility. It may be speculated that resin droplets formed in the cell lumen under wet curing conditions provided a higher surface area than the continuous, circular layer in dry cured cells. This may have contributed to the higher concentration of exchanged $\mathrm{H}$ in wet cured samples. Furthermore, the positive cell wall bulking in dry cured wood may have reduced accessibility of sorption sites to (deuterated) water by steric hindrance. Such an effect has been suggested for wood treated with acetic anhydride, where the reduction in free space within the cell wall matrix by the presence of the modification agent reduced the $\mathrm{OH}$ group accessibility more rapidly than estimated by the amount of reacted $\mathrm{OH}$ groups [42].

However, a lower sorption site accessibility only partly explained the lower moisture uptake in dry cured compared to wet cured wood. Differences between dry and wet cured wood were also seen when relating the amount of absorbed $\mathrm{D}_{2} \mathrm{O}$ to the amount of exchanged $\mathrm{H}$. Resin modification decreased the ratio of absorbed $\mathrm{D}_{2} \mathrm{O}$ per exchanged $\mathrm{H}$ with increasing solid content of the impregnation solution (Fig. 7c). This could primarily be assigned to the lower ratio of the pure MF resin (ca. 0.5). However, at the same resin load, dry cured samples had a lower ratio of absorbed $\mathrm{D}_{2} \mathrm{O}$ per exchanged $\mathrm{H}$. Presumably, the occupation of water-accessible cell wall pores in dry cured wood (indicated by the positive cell wall bulking) reduced the number of accessible sorption sites that were simultaneously active in water sorption, as suggested by Willems [37]. Water sorption is a dynamic process of simultaneous absorption and desorption, which allows (deuterated) water molecules to migrate to different sorption sites. This dynamic migration ensured that all accessible sorption sites had their hydrogen exchanged for deuterium, while the reduced space in dry cured cell walls reduced the amount of water molecules that could be accommodated at the same time.

\section{Conclusions}

Fully cured MF resin lacked the steep increase in MC at elevated humidity that was evident in unmodified wood, and this affected the course of the moisture content of resin-modified wood in the hygroscopic range. Furthermore, the sorption behavior of MF resin was dependent on the surface area and the corresponding change in sorption site accessibility. This may have been relevant in view of the different shapes of the MF resin deposits in the cell lumen of the differently cured wood blocks. In resin-modified wood, the occupation of water-accessible cell wall pores by MF resin (cell wall bulking) counterbalanced the moisture uptake of the resin and reduced the equilibrium moisture content of wood by a constant factor. Dry curing resulted in a higher cell wall bulking and, hence, in a lower moisture uptake compared to wood that was treated under wet curing conditions. This was assigned to a slightly lower accessibility of sorption sites and a further decrease in the number of simultaneously active sorption sites in dry cured wood.

\section{Acknowledgement}

Open access funding provided by Aalto University. This work made use of the Aalto University Nanomicroscopy Center (Aalto-NMC) premises. The financial support by the Academy of Finland (Grant No. 309881) is acknowledged.

\section{Author contributions}

M.A. conceived the research and designed the experiments. A.K. prepared the wood blocks and performed the treatments. D.A. conducted the SEM measurements. M.A. performed the water vapor sorption, $\mathrm{H}-\mathrm{D}$ exchange and spectroscopic measurements. All authors interpreted the results. M.A. wrote the manuscript. All authors read and approved of the final manuscript.

Electronic supplementary material: The online version of this article (https://doi.org/10.1007/s108 53-020-04814-0) contains supplementary material, which is available to authorized users. 
Open Access This article is licensed under a Creative Commons Attribution 4.0 International License, which permits use, sharing, adaptation, distribution and reproduction in any medium or format, as long as you give appropriate credit to the original author(s) and the source, provide a link to the Creative Commons licence, and indicate if changes were made. The images or other third party material in this article are included in the article's Creative Commons licence, unless indicated otherwise in a credit line to the material. If material is not included in the article's Creative Commons licence and your intended use is not permitted by statutory regulation or exceeds the permitted use, you will need to obtain permission directly from the copyright holder. To view a copy of this licence, visit http://creativecommons.org/licen ses/by $/ 4.0 /$.

\section{References}

[1] Skaar C (1988) Wood-water relations. Springer, Berlin

[2] Hoadley RB (2000) Understanding wood: a craftsman's guide to wood technology. The Taunton Press, Newton

[3] Hosseinpourpia R, Adamopoulos S, Mai C (2015) Dynamic vapour sorption of wood and holocellulose modified with thermosetting resins. Wood Sci Technol 50:165-178

[4] Lukowsky D (2002) Influence of the formaldehyde content of waterbased melamine formaldehyde resins on physical properties of Scots pine impregnated therewith. Holz Roh Werkst 60:349-355

[5] Pittman CU, Kim MG, Nicholas DD, Wang L, Kabir FRA, Schultz TP, Ingram LL (1994) Wood enhancement treatments I. Impregnation of Southern yellow pine with melamine-formaldehyde and melamine-ammeline-formaldehyde resins. J Wood Chem Technol 14:577-603

[6] Behr G, Bollmus S, Gellerich A, Militz H (2018) The influence of curing conditions on the properties of European beech (Fagus sylvatica) modified with melamine resin assessed by light microscopy and SEM-EDX. Int Wood Prod J 9:22-27

[7] Kielmann BC, Adamopoulos S, Militz H, Koch G, Mai C (2014) Modification of three hardwoods with an N-methylol melamine compound and a metal-complex dye. Wood Sci Technol 48:123-136

[8] Mahnert K-C, Adamopoulos S, Koch G, Militz H (2012) Topochemistry of heat-treated and $N$-methylol melaminemodified wood of koto (Pterygota macrocarpa K. Schum.) and limba (Terminalia superba Engl. et. Diels). Holzforschung 67:137-146
[9] Pizzi A (2003) Melamine-formaldehyde adhesives. In: Pizzi A, Mittal KL (eds) Handbook adhesive technology, 2nd edn. Marcel Dekker, New York

[10] West HJ, Watt WT (1950) Processes of preparing watersoluble melamine-formaldehyde resins and products thereof. Patent US2529856A

[11] Rapp AO, Bestgen H, Adam W, Peek R-D (2005) Electron energy loss spectroscopy (EELS) for quantification of cellwall penetration of a melamine resin. Holzforschung 53:111-117

[12] Gindl W, Zargar-Yaghubi F, Wimmer R (2003) Impregnation of softwood cell walls with melamine-formaldehyde resin. Bioresour Technol 87:325-330

[13] Gindl W, Gupta HS (2002) Cell-wall hardness and Young's modulus of melamine-modified spruce wood by nano-indentation. Compos Part A Appl Sci Manuf 33:1141-1145

[14] Merline DJ, Vukusic S, Abdala AA (2012) Melamine formaldehyde: curing studies and reaction mechanism. Polym J 45:413-419

[15] Yasuda R, Minato K, Norimoto M (1994) Chemical modification of wood by non-formaldehyde cross-linking reagents. Wood Sci Technol 28:209-218

[16] Himmel S, Mai C (2015) Effects of acetylation and formalization on the dynamic vapor sorption behavior of wood. Holzforschung 69:633-643

[17] Thygesen LG, Engelund ET, Hoffmeyer P (2010) Water sorption in wood and modified wood at high values of relative humidity. Part I: results for untreated, acetylated, and furfurylated Norway spruce. Holzforschung 64:315-323

[18] Devallencourt C, Saiter JM, Capitaine D (2000) Reactions between melamine formaldehyde resin and cellulose: influence of pH. J Appl Polym Sci 78:1884-1896

[19] Wimmer R, Kläusler O, Niemz P (2013) Water sorption mechanisms of commercial wood adhesive films. Wood Sci Technol 47:763-775

[20] Soles CL, Chang FT, Bolan BA, Hristov HA, Gidley DW, Yee AF (1998) Contributions of the nanovoid structure to the moisture absorption properties of epoxy resins. J Polym Sci B Polym Phys 36:3035-3048

[21] Smith PM, Fisher MM (1984) Non-fickian diffusion of water in melamine-formaldehyde resins. Polymer 25:84-90

[22] Brewis DM, Comyn J, Phanopoulos C (1987) Effect of water on some wood adhesives. Int J Adhes Adhes 7:43-48

[23] Altgen M, Awais M, Altgen D, Klüppel A, Mäkelä M, Rautkari L (2020) Distribution and curing reactions of melamine formaldehyde resin in cells of impregnationmodified wood. Sci Rep 10(3366):1-10

[24] Klüppel A, Mai C (2013) The influence of curing conditions on the chemical distribution in wood modified with thermosetting resins. Wood Sci Technol 47:643-658 
[25] Thybring EE, Kymäläinen M, Rautkari L (2018) Experimental techniques for characterising water in wood covering the range from dry to fully water-saturated. Wood Sci Technol 52:297-329

[26] Glass SV, Boardman CR, Zelinka SL (2017) Short hold times in dynamic vapour sorption measurements mischaracterize the equilibrium moisture content of wood. Wood Sci Technol 51:243-260

[27] Greenspan L (1977) Humidity fixed points of binary saturated aqueous salt solutions. J Res Natl Bur Stand Phys Chem 81A:89-96

[28] Larkin PJ, Makowski MP, Colthup NB (1999) The form of the normal modes of s-triazine: infrared and Raman spectral analysis and ab initio force field calculations. Spectrochim Acta A Mol Biomol Spectrosc 55:1011-1020

[29] Scheepers ML, Gelan JM, Carleer RA, Adriaensens PJ, Vanderzande DJ, Kip BJ, Brandts PM (1993) Investigation of melamine-formaldehyde cure by Fourier transform Raman spectroscopy. Vib Spectrosc 6:55-69

[30] Scheepers ML, Meier RJ, Markwort L, Gelan JM, Vanderzande DJ, Kip BJ (1995) Determination of free melamine content in melamine-formaldehyde resins by Raman spectroscopy. Vib Spectrosc 9:139-146

[31] Hill CG, Hedren AM, Myers GE, Koutsky JA (1984) Raman spectroscopy of urea-formaldehyde resins and model compounds. J Appl Polym Sci 29:2749-2762

[32] Weiss S, Urdl K, Mayer HA, Zikulnig-Rusch EM, Kandelbauer A (2019) IR spectroscopy: Suitable method for determination of curing degree and crosslinking type in melamine-formaldehyde resins. J Appl Polym Sci 136:47691

[33] Klüppel A (2017) Hardness and indentation modulus of resin-treated wood. Int Wood Prod J 8:41-44

[34] Nishida M, Tanaka T, Miki T, Hayakawa Y, Kanayama K (2019) Integrated analysis of modified Japanese cypress using solid-state NMR spectra and nuclear magnetic relaxation times. Cellulose 26:3625-3642

[35] Hill CAS (2008) The reduction in the fibre saturation point of wood due to chemical modification using anhydride reagents: a reappraisal. Holzforschung 62:423-428

[36] Xie Y, Hill CS, Xiao Z, Mai C, Militz H (2011) Dynamic water vapour sorption properties of wood treated with glutaraldehyde. Wood Sci Technol 45:49-61

[37] Willems W (2018) Hygroscopic wood moisture: single and dimerized water molecules at hydroxyl-pair sites? Wood Sci Technol 52:777-791

[38] Murr A (2019) The relevance of water vapour transport for water vapour sorption experiments on small wooden samples. Transp Porous Media 128:385-404

[39] Strømdahl K (2000) Water sorption in wood and plant fibres. Ph.D. Dissertation. Technical University of Denmark

[40] Thybring EE, Thygesen LG, Burgert I (2017) Hydroxyl accessibility in wood cell walls as affected by drying and rewetting procedures. Cellulose 24:2375-2384

[41] Uimonen T, Hautamäki S, Altgen $M$, Kymäläinen $M$, Rautkari L (2020) Dynamic vapour sorption protocols for the quantification of accessible hydroxyl groups in wood. Holzforschung 74:412-419

[42] Beck G, Strohbusch S, Larnøy E, Militz H, Hill C (2017) Accessibility of hydroxyl groups in anhydride modified wood as measured by deuterium exchange and saponification. Holzforschung 72:17-23

[43] Altgen M, Willems W, Hosseinpourpia R, Rautkari L (2018) Hydroxyl accessibility and dimensional changes of Scots pine sapwood affected by alterations in the cell wall ultrastructure during heat-treatment. Polym Degrad Stab 152:244-252

Publisher's Note Springer Nature remains neutral with regard to jurisdictional claims in published maps and institutional affiliations. 